\title{
AVAILABLE TO ALL, PRODUCED BY FEW: THE ECONOMIC AND CULTURAL IMPACT OF EUROPE'S DIGITAL SINGLE MARKET STRATEGY WITHIN THE AUDIOVISUAL INDUSTRY
}

\begin{abstract}
Charles A. Weiss*
Currently, Europeans traveling abroad confront frustrations when trying to access their subscriptions to Internet streaming services such as Netflix or Amazon Prime. Often, their attempts to access a movie or show are met with a message stating something along the lines of: "We are sorry. This content is not available in your country or territory." In the vernacular of the audiovisual industry, their content is "geo-blocked" in that nation. This is due to the fact that, under the European Union's current regulatory framework, producers of audiovisual content finance and distribute their shows in a system based on territorial exclusivity. Territorial exclusivity entails selling exclusive broadcast rights for audiovisual content to specific broadcasters and online platforms on a territory-by-territory or country-by-country basis. However, this may all be changing soon for the European Union. In May 2015, the European Commission announced its plan for a Digital Single Market, a multifaceted proposal aiming to tear down regulatory and geo-blocking walls between the European Union's Member States and to create a single, pan-European online market.

This Note explores the potential financial and cultural implications of this DSM strategy for the film and television

* J.D. Candidate 2017, Columbia Law School; B.A. 2011, Georgetown University. Many thanks to Professor Lance Liebman for his thoughtful guidance and feedback during the production of this Note. Thanks are also due to the brilliant staff and editorial board of the Columbia Business Law Review for their diligent work in preparing this Note for publication.
\end{abstract}


industries in the European Union and the United States. The benefits of a pan-European territory for audiovisual content distribution rights will be immediately clear to consumers. Cross-border portability and availability of subscriptions, movies, and shows will likely be applauded. However, this Note suggests the potential costs of such a unification effort, although less immediately evident, may be substantial. In particular, cultural diversity within the European Union and the ability of smaller nations' audiovisual industry players to compete may suffer if the costs of production and distribution increase to a pan-European scale. Throughout the growth and development of the European Union, there has been a struggle between concerns for harmonization and unification among the Member States and concerns for the preservation of unique cultural identities and diversity. The debate over the $D S M$ is a microcosm of this balancing act, the latest chapter of an ongoing tension to define to what lengths the EU should go in unifying its Members. The European Commission's ultimate determination of how to enact the DSM will signal how they currently prioritize these competing considerations.

I. Introduction

II. The European Audiovisual Sector

A. The Legal Framework of Territorial

Exclusivity

1. The Principle of Territoriality in

Copyright

2. Development of Cross-Border Recognition ..886

3. Harmonization of EU Law in the

Audiovisual Sector.

B. Territorial Exclusivity in Practice

1. Commercial Considerations in Licensing

Deals

2. Geo-blocking

3. Circumvention and VPN

III. The DSM: Problems to Address, Proposed Reforms, and Potential Ramifications 900

A. Problems Within the EU's Digital Audiovisual Industry 
1. Falling Behind Internationally .900

2. Changes in Consumer Behavior and the Demand for Cross-Border Portability and Accessibility .902

3. Market Segmentation ..................................905

B. The DSM Strategy_Proposed Actions................906

1. Background ...............................................906

2. The EC's December 2015 Proposed

Regulations .............................................907

a. Unjustified Geo-Blocking....

b. Modernization of European Copyright Law 911

C. Why Territorial Exclusivity Should be

Preserved: Economic and Cultural Costs .914

1. Economic 915

2. Cultural. 917

IV. Balancing Concerns of Territorial Exclusivity with Cross-Border Portability and Pending Developments in the DSM's Implementation........... 919

A. Potential Solutions ............................................919

1. Commercial Considerations........................920

B. Ongoing Developments in the DSM Timeline ....921

V. Conclusion 922

\section{INTRODUCTION}

In May 2015, the European Commission ("EC") announced its long-awaited strategy for a Digital Single Market ("DSM") among the European Union's twenty-eight Member States. The strategy comprised a multifaceted proposal aiming to "tear down regulatory walls and finally move from 28 national markets to a single one." Identified by EC President Jean-Claude Juncker as one of his ten

1 European Commission Press Release IP/15/4919, A Digital Single Market for Europe: Commission Sets Out 16 Initiatives to Make It Happen (May 6, 2015), http://europa.eu/rapid/press-release_IP-15-4919_en.htm [https://perma.cc/Y4EP-9YHM]. 
political priorities, ${ }^{2}$ the DSM strategy reflects the EC's intention to create a free-moving economy "where individuals and businesses can seamlessly access and exercise online activities under conditions of fair competition, and a high level of consumer and personal data protection, irrespective of their nationality or place of residence." 3 The DSM strategy is complex and wide in scope, proposing reforms in areas including e-commerce, cyber-security, telecommunications, cloud services, parcel delivery, and audiovisual content, among others. ${ }^{4}$ If successful, the EC estimates a fully functioning DSM could potentially contribute $€ 415$ billion to European gross domestic product and allow consumers and businesses alike to benefit from the larger unified marketplace. ${ }^{5}$

Despite its touted benefits, the DSM strategy has its critics. For example, members of the film and television industries in Europe and the United States are concerned about the economic and cultural ramifications of a panEuropean digital market that no longer recognizes the traditional territorial barriers between Member States or the exclusive copyright and distribution rights for digital content

2 See Jean-Claude Juncker, A New Start for Europe: My Agenda for Jobs, Growth, Fairness and Democratic Change (Jul. 15, 2014), http://ec.europa.eu/priorities/sites/beta-political/files/juncker-politicalguidelines-speech_en_0.pdf [https://perma.cc/Z8PD-YUVC].

3 Communication from the Commission to the European Parliament, the Council, the European Economic and Social Committee and the Committee of the Regions: A Digital Single Market Strategy for Europe, at 3, COM (2015) 192 final (May 6, 2015), http://ec.europa.eu/priorities/digital -single-market_en (follow "Communication on Digital Single Market" hyperlink under "Documents" subsection) [https://perma.cc/G328-A8CN].

4 See European Commission Press Release IP/15/4919, supra note 1.

5 Commission Staff Working Document: A Digital Single Market Strategy for Europe-Analysis and Evidence, at 5, SWD (2015) 100 final (May 6, 2015), http://ec.europa.eu/priorities/digital-single-market_en (follow "Staff working paper on Digital Single Market" hyperlink under "Documents" subsection) [https://perma.cc/GDV4-4JLM] [hereinafter Commission Staff Working Document]. 
held within them. ${ }^{6}$ Their uneasiness centers on the EC's commitment to ending "unjustified geo-blocking" and creating a "modern, more European copyright law" that harmonizes different national copyright regimes. ${ }^{7}$

Under the current European regulatory framework, producers can finance their shows and films through means of territorial exclusivity. Territorial exclusivity entails selling exclusive broadcast rights to different broadcasters and online platforms (e.g., Netflix) territory-by-territory within the EU. Accordingly, content producers can maximize their revenues by selling the same content repeatedly to audiences in different territories. ${ }^{8}$ To effectuate these territorial copyright and distribution rights, content is "geo-blocked" to users in outside markets. ${ }^{9}$ For example, the film rights Netflix owns in Germany may be different than the film rights Netflix owns in the Netherlands. As such, when German tourists visit the Netherlands and attempt to access their Netflix accounts, they will be geo-blocked from accessing the usual catalogue of shows and films included in their German subscriptions.

Under the DSM strategy, however, the legality of these geo-blocking mechanisms is in doubt. ${ }^{10}$ The EC intends for

6 See Stephen Edwards \& James Tobias, Reed Smith LLP, The European Digital Single Market: Where Are We Now?, JD SuPRA (Oct. 21, 2015), http://www.jdsupra.com/legalnews/the-european-digital-single-mar ket-81315 [https://perma.cc/GS8J-8SDK] (summarizing the "apprehension" within the audiovisual industry caused by the DSM strategy); see also Scott Roxborough, Can Europe Set Up a Digital Single Market Without Killing Copyrights? (Analysis), THE HollywOOD REP. (May 8, 2015, 9:11 $\mathrm{AM})$, http://www.hollywoodreporter.com/news/europe-digital-single-market -analysis-794386 [https://perma.cc/WM53-N3UQ] (quoting participants in the film and television industries voicing their concerns with the DSM).

7 See European Commission Press Release IP/15/4919, supra note 1.

8 See Alex Spence, In Europe, Debate over Streaming Video and GeoBlocking, PoliTiCO (Sept. 18, 2015, 9:26 AM), http://www.politico.com/medi a/story/2015/09/in-europe-debate-over-streaming-video-and-geo-blocking004149 [https://perma.cc/C8PW-H6VV].

9 Id.

10 Andrus Ansip, the former Estonian prime minister and current EU's DSM commissioner overseeing the reforms, has expressed in no 
the DSM strategy to end "unjustified geo-blocking" to create greater portability and accessibility to digital content throughout the continent while "nurturing cultural diversity" and "opening new opportunities for creators and the content industry." 11 Members of the film and television industries fear, however, that while the end of geo-blocking and the territoriality of copyright may increase the portability of content, it will in fact have a negative effect on cultural diversity and the ability of smaller participants to compete in the larger market. ${ }^{12}$ This fear stems in part from the EC's failure to clearly differentiate "unjustified" from "justified" geo-blocking practices. ${ }^{13}$ In sum, while a DSM is an end goal supported by a vast majority of member states and lawmakers, the means by which that end is realized is a topic of debate, particularly in the realm of copyright law.

This Note provides a survey of the potential financial and cultural implications of the DSM strategy in the film and television industries, both within the EU and the United States. The development and implementation of the EC's DSM strategy remains in its early stages, with preliminary legislative proposals concerning geo-blocking and copyright

uncertain terms his distaste for geo-blocking measures, stating: "Deep in my heart, I hate [geo-blocking]. It is old-fashioned and it is not fair." Duncan Robinson, EU's Andrus Ansip Unveils Plans to Overhaul Digital Market, Fin. TIMEs (Mar. 25, 2015, 3:09 PM), http://www.ft.com/ (search for the title through the search bar); see also Jennifer Baker, 'I Don't NEED to Pay' to Watch Football, Thunders EU Digi-Czar, THE REgIsTeR (Dec. 9, 2014, 3:03 PM), http://www.theregister.co.uk/2014/12/09/ansips_lo ve_of_football_drives_copyright_overhaul [https://perma.cc/2GL9-WCR2] ("Ansip . . . said: 'I pay my taxes in Estonia, so why, when in Brussels, can't I watch content I bought legally. As a [license] payer I should be able to watch the football, but I find it's blocked, blocked, blocked!"').

11 See European Commission Press Release IP/15/4919, supra note 1.

12 See Edwards \& Tobias, supra note 6.

13 See Roxborough, supra note 6. See also Jaroen Jansen, DLA Piper, Upcoming EU Copyright Reform, JD SUPRA (Aug. 4, 2015), http://www.jdsupra.com/legalnews/upcoming-eu-copyright-reform-79271 [https://perma.cc/XJ8L-LSQF] (noting the pending challenge of differentiating between justified from unjustified geo-blocking). 
reform having been released in December 2015. ${ }^{14}$ These initial proposals are not expected to come into force until 2017, indicating that it will be some time until the full DSM strategy takes effect within the EU and the ramifications of the policies can be examined. ${ }^{15}$ This Note aims to explain the impetus for a DSM within the audiovisual industry, discuss how the EC is working to achieve a DSM, and consider the costs and benefits consumers and businesses may see as a result of the EC's actions. Part II summarizes the state of the European audiovisual sector and the legal framework the film and television industries currently operate within, both on a European and national level. This includes a discussion detailing the mechanisms of territorial exclusivity and geoblocking. Part III discusses the problems of portability and cross-border access currently within the film and television industries, the DSM's plans to address these problems, as well as the potential cultural and economic issues the DSM strategy poses for consumers and businesses. It suggests that territorial exclusivity must be preserved in order to protect the viability of smaller players in the European audiovisual industry, as well as cultural diversity. Part IV discusses pending developments and next-steps for the EC in implementing the DSM, including suggestions for how the EC can better increase portability of digital content among EU nations, yet still allow for a system of territorial exclusivity. These suggestions include addressing portability concerns through commercial and contractual instruments as opposed to governmental regulation, and the idea of a "Virtual Passport," which allows physical travelers to travel digitally as well. The EC's ultimate determination regarding

14 See European Commission Press Release IP/15/6261, Commission Takes First Steps to Broaden Access to Online Content and Outlines Its Vision to Modernise EU Copyright Rules (Dec. 9, 2015), http://europa.eu/ra pid/press-release_IP-15-6261_en.htm [https://perma.cc/RQZ9-33L4].

15 Tom Scourfield et al., CMS Cameron McKenna, The EU's Portability Proposal - an Attainable Step Towards a Digital Single Market, CMS: LAW-Now (Dec. 14, 2015), http://www.cms-lawnow.com (click "View more alerts" hyperlink and search by date) [https://perma.cc/3M6H$\mathrm{K} 6 \mathrm{ME}]$. 
the DSM will depend on their prioritization of many competing considerations, including consumer experience, protection of European business from American competition, the homogenizing of the European Union, and the preservation of cultural diversity within Member States.

\section{THE EUROPEAN AUDIOVISUAL SECTOR}

\section{A. The Legal Framework of Territorial Exclusivity}

\section{The Principle of Territoriality in Copyright}

Currently, stakeholders in the European Union's audiovisual industries operate under a framework of territorial copyrights, meaning they negotiate, license, and acquire the rights to works of audiovisual content (e.g., film, television shows, and sports broadcasts) on a territory-byterritory basis. ${ }^{16}$ Accordingly, the European Commission traditionally has defined the geographic scope of broadcasting markets for antitrust enforcement purposes as national or based on areas of shared linguistic or sociocultural background (e.g., a copyright holder may license broadcasting rights to Germany, Austria, and the German speaking parts of Switzerland and Luxembourg as a single territory). ${ }^{17}$ This practice is grounded in the principle of territoriality in copyright law. According to this principle, each country may promulgate its own copyright rules within the broader framework of relevant international and EU laws. ${ }^{18}$

Inherently, copyright protection over a work entitles a holder to a degree of exclusivity over the use of that work. The geographic scope of such exclusivity granted under any Member State's copyright law is limited to the territorial

16 Francisco JaVier Cabrera BlázQuez ET AL., IRIS Plus 2015-2: TERRITORIALITY AND ITS IMPACT ON THE FINANCING OF AUdIOVISUAL WORKS 132-33 (2015), http://www.obs.coe.int (click "Publications" tab and click “2015”) [https://perma.cc/S3CN-MK9D] [hereinafter BLÁZQUEZ ET AL.].

17 Id.

$18 I d$. at 27. 
boundaries of that Member State. ${ }^{19}$ The significance of this framework is that copyright holders, such as authors and producers, have the right to grant licenses on a territorial basis. ${ }^{20}$ As a result, a service or content provider distributing online copyrighted works in multiple Member States must obtain licenses covering each relevant territory. ${ }^{21}$

Critics of the principle of territoriality within EU copyright law point to several legal consequences. First, variation in complex national copyright regimes among states makes compliance more difficult, creating legal uncertainty and additional legal costs. ${ }^{22}$ Second, for those wanting to offer a copyrighted work in multiple territories, obtaining multiple licenses raises transaction costs, which are borne by both license-acquirers and their consumers. ${ }^{23}$ Last, authors, publishers, broadcasters, and other rightholders must bear increased monitoring and enforcement costs to ensure others do not violate their respective rights. ${ }^{24}$

Nevertheless, copyright territoriality also generates clear benefits for content producers and derivative right-holders. The key upshot of the principle is that territorial licensing provides authors and content producers the opportunity to receive higher remuneration for their works. Furthermore, territoriality allows for price discrimination between national markets, enabling rights-holders to cater their offerings to the preferences and economics of each territory. ${ }^{25}$ Territorial licensing also facilitates the marketing and distribution of works in foreign markets, where license-

19 P. Bernt Hugenholtz, Copyright Territoriality in the European Union 2 (Eur. Parliament Directorate Gen. for Internal Policies, Policy Dep't C: Citizens' Rights and Constitutional Affairs ed., 2010), http://www.europarl.europa.eu/RegData/etudes/note/join/2010/419621/IPO L-JURI_NT(2010)419621_EN.pdf [https://perma.cc/GT7X-5Z2M].

20 BLÁZQUEZ ET AL., supra note 16, at 27.

21 Id. at 30.

22 Hugenholtz, supra note 19, at 2, 5-6.

23 Id. at $2,12$.

24 Id. at 2,11 .

25 Id. at $2,11-12$. 
acquirers may need to modify such works for consumption by local audiences. ${ }^{26}$ Lastly, each nation or territory has the ability to better control internal competition and protect cultural subsidies through means such as collective rights management societies. ${ }^{27}$

\section{Development of Cross-Border Recognition}

In the EU's fragmented system of territorial copyrights, Member States must mutually respect the copyright protections granted by other Member States in order for the protection to be meaningful. Prior to the nineteenth century, a work protected in one nation was not necessarily protected in other nations, resulting in the unauthorized and unremunerated copying of creative works outside the nation. ${ }^{28}$ Through a series of conventions, agreements, and directives, multilateral solutions emerged for the crossborder recognition of copyright protection. The initial step was the adoption in 1886 of the Berne Convention, which provided authors with certain minimum rights of protection in all of the Convention's contracting states. ${ }^{29}$ Later, the Agreement on Trade-Related Aspects of Intellectual Property Rights ("TRIPS"), negotiated in 1994, added heightened obligations to the mandatory protection standards of the Berne Convention. ${ }^{30}$ Around the same time, agreements through the World Intellectual Property Organization

26 Id. at $11-12$.

27 Id. at 2, 12. As Dr. Hugenholtz discusses, collective rights management societies currently exist on a territorial basis. These societies capitalize on collectively pooled intellectual property rights, funneling the proceeds not only to entitled right-holders, but also cultural and social funds that benefit local authors. "[These] societies thus play an important role in fostering 'cultural diversity' in the EU. Removing the territorial aspect of performance and communication rights would not only affect these de facto cultural subsidies, but also undermine the societies' very existence, except for a handful of societies that are large enough, or sufficiently efficient, to compete at the European level.” Id. at 12.

28 BLÁZQUEZ ET AL., supra note 16, at 28.

29 Id. at 29.

$30 \mathrm{Id}$. 
("WIPO"), such as the WIPO Copyright Treaty adopted in December 1996, responded to developments in the Internet and digitization while building on the principle of territoriality. ${ }^{31}$

\section{Harmonization of EU Law in the Audiovisual Sector}

Due to the cross-border nature of audiovisual commerce within the EU, a tension exists between Members States when their audiovisual regulations or copyright regimes conflict. ${ }^{32}$ Through a series of agreements and directives, the EU has alleviated some of this tension regarding competing national audiovisual regulations and has helped provide legal certainty for content distributors and producers. ${ }^{33}$ Nonetheless, Member States' copyright regimes remain highly fragmented, forcing members of the audiovisual industry to comply with the varying copyright laws of each Member State where they distribute content. ${ }^{34}$

Based on the principle of territoriality, a nation principally develops and controls its own audiovisual regulations. Member States are free to enact rules regarding broadcasters, distributors, and on-demand services within their jurisdiction, including regulations requiring financial contributions and the promotion of European-produced content. ${ }^{35}$ However, as mentioned, the EU has passed a series of directives to harmonize certain aspects of legal regimes between its Member States, thereby alleviating the negative consequences of territorial laws, ${ }^{36}$ as well as

31 Id. at $29-30$.

32 See generally id.

33 See id. at 30.

34 Id. See also Estrella Gomez \& Bertin Martens, Language, Copyright and Geographic Segmentation in the EU Digital Single Market for Music and Film 1 (Eur. Comm'n, Digital Economy Working Paper 2015-04, 2015), https://ec.europa.eu/jrc/sites/default/files/JRC92236_Language_Cop yright.pdf [https://perma.cc/YX8U-NDVW].

35 BLÁZQUEZ ET AL., supra note 16, at 23-24.

36 E.g., legal uncertainty and higher transaction costs. 
promoting a unified EU market. ${ }^{37}$ The Information Society Directive, for instance, harmonizes the legal treatment of rights of reproduction and distribution, anti-copying devices, and rights management systems. ${ }^{38}$ The Satellite and Cable Directive ("SatCab Directive") introduced the "country of origin" principle to facilitate cross-border transmission of audiovisual programs by satellite. ${ }^{39}$ Under the "country of origin" principle, audiovisual service providers can operate in all Member States across Europe but must only abide by the rules of the Member State where they are established. ${ }^{40}$ Establishment is based on factors such as the location of the head office, the origin of editorial decisions, the location of a significant part of the workforce involved in the pursuit of the audiovisual media service activity, and/or the use of satellite capacity. ${ }^{41}$

The Audiovisual Media Services Directive ("AVMSD") explicitly applies the "country of origin" principle to all audiovisual media services, including television broadcasts and on-demand services. ${ }^{42}$ Article 2(1) of AVMSD states: "Each Member State shall ensure that all audiovisual media services transmitted by media service providers under its jurisdiction comply with the rules of the system of law applicable to audiovisual media services intended for the public in that Member State." 43 Article 3(1) of AVMSD builds on this principle, ensuring that compliant services are able to

37 BLÁZQUEZ ET AL., supra note 16, at 30.

38 Id.

39 Id.

40 Commission Staff Working Document, supra note 5, at 43.

41 BLÁZqUEZ ET AL., supra note 16, at 23, 38-39.

42 Commission Staff Working Document, supra note 5, at 43-44.

43 Directive 2010/13/EU of the European Parliament and of the Council of 10 March 2010 on the Coordination of Certain Provisions Laid Down by Law, Regulation or Administrative Action in Member States Concerning the Provision of Audiovisual Media Services (Audiovisual Media Services Directive), art. 2, 2010 O.J. (L 95) 13, http://eurlex.europa.eu (search for "Directive 2010/13/EU") [https://perma.cc/93Q9RD62]. 
circulate freely in other Member States. ${ }^{44}$ The AVMSD sets a baseline for audiovisual industry regulations and then allows for Member States to build upon it; Article 4(1) states that Member States can "require media service providers under their jurisdiction to comply with more detailed or stricter rules in the fields coordinated by this Directive provided that such rules are in compliance with Union law." ${ }^{45}$ In accordance with the "country of origin" principle, however, Member States with higher standards may not restrict the reception of media services from providers subject to the jurisdiction of Member States with lower standards. ${ }^{46}$ The key benefit of the "country of origin" principle is that it provides legal certainty, allowing a provider established in one state to freely distribute an audiovisual media service across other states without needing further authorization or compliance with these other states' rules. ${ }^{47}$

While the "country of origin" principle articulated in the AVMSD is focused on harmonizing EU Member State audiovisual rules, it does not apply to national copyright regimes. Contrary to the AVMSD, Article 3(3) of the eCommerce Directive applies the "country of destination" principle to the copyright sector. ${ }^{48}$ According to the "country

44 AVMSD Article 3(1) reads: "Member States shall ensure freedom of reception and shall not restrict retransmissions on their territory of audiovisual media services from other Member States for reasons which fall within the fields coordinated by this Directive." Id. art. 3.

45 Id. art. 4 , at 14.

46 Commission Staff Working Document, supra note 5, at 43.

47 BlÁzQUeZ ET AL., supra note 16, at 34; see also Commission Staff Working Document, supra note 5, at 45 ("[The country of origin principle] creates legal certainty, saves costs and increases the number of potential viewers. It has facilitated the development of new trans-border business models.").

48 Directive 2000/31/EC, of the European Parliament and of the Council of 8 June 2000 on Certain Legal Aspects of Information Society Services, in Particular Electronic Commerce, in the Internal Market (Directive on Electronic Commerce), art. 3, 2000 O.J. (L 178) 9, http://eurlex.europa.eu (search for "Directive 2000/31/EU") [https://perma.cc/XQ37$88 \mathrm{KC}]$; BLÁZQUEZ ET AL., supra note 16 , at 40 (“[C]ontrary to what happens 
of destination" principle, the Member State receiving audiovisual services determines the applicable copyright regulations and also is responsible for monitoring and enforcement. ${ }^{49}$ This directly contrasts with audiovisual content-related issues, where the Member State of establishment has the right to regulate and intervene under the AVMSD "country of origin" principle.50 As a result, within the realm of copyright, EU law has had little impact on the territorial fragmentation of Member States' copyright regimes. ${ }^{51}$

The SatCab Directive introduces the "country of origin" principle as governing communications to the public by satellite. However, contractual licensing practices and signal encryption techniques often circumvent application of this principle. $^{52}$ Furthermore, while Article 20 of the Services Directive ("SD") explicitly prohibits price discrimination practices and availability restrictions between Member States, it provides an exception where objective reasons to utilize such practices exist. ${ }^{53}$ The territoriality of copyright is often claimed as a legitimate objective reason. ${ }^{54}$ In the end, "the territoriality principle mostly prevails and any service provider offering[,] e.g.[,] copyrighted works online in more than one member state will have to clear licences covering all of these countries." 55

in the AVMSD, Article 3(3) of the e-Commerce Directive lists the sectors where this principle is reversed in favour of the country of destination.").

49 BLÁZqUEZ ET AL., supra note 16, at 34, 40.

50 Id.

51 Id. at 40.

52 BLÁZQUEZ ET AL., supra note 16 , at 30.

53 Gomez \& Martens, supra note 34 , at 1.

54 Id.

55 BlÁzQUez ET AL., supra note 16, at 30. See also Gomez \& Martens, supra note 34, at 1 ("The EU Copyright Directive (2001) has to some extent harmonized copyright law between Member States but it remains essentially national law.”). 


\section{B. Territorial Exclusivity in Practice}

\section{Commercial Considerations in Licensing Deals}

The preservation of territoriality in copyright to this point has largely been a reflection of its economic necessity. Territorial licensing plays a fundamental role in the financing of films and television shows, and many stakeholders in the audiovisual industry consider it to be an indispensable legal and business framework. ${ }^{56}$ As EU law stands now, the rights for audiovisual content are generally negotiated on a country-by-country basis, as well as on the basis of common linguistic area or common socio-cultural background (e.g., Scandinavia). ${ }^{57}$ The exclusive territorial basis on which rights are sold allows rights-holders to target markets with higher demand to maximize revenues and tailor content to the preferences of the audiences in each market. ${ }^{58}$

Audiovisual works are unique relative to other copyrightable works, in part due to their expensive production costs and multitude of rights-holders, which may include the screenwriter, film director, composer of the soundtrack, and others. ${ }^{59}$ Due to high production and marketing costs, films are risky investments, often taking several years to develop and produce. ${ }^{60}$ In order to obtain the necessary financing to produce their films, many filmmakers rely on the territorial sale of exclusive distribution rights. ${ }^{61}$

56 Scott Roxborough, Europe to Unveil Plans to Reform Copyright, Introduce Digital Single Market, Hollywood REP. (Dec. 9, 2015, 12:09 AM), http://www.hollywoodreporter.com/news/europe-unveils-plansreform-copyright-847135 [https://perma.cc/2V8W-FT9R].

57 BLÁZQUEZ ET AL., supra note 16, at 33.

58 Scourfield et al., supra note 15.

59 BLÁZQUEZ ET AL., supra note 16, at 43.

$60 \quad I d$. at 18.

61 Charles-Edouard Renault \& Rob H. Aft, From Script to ScReen: The Importance of Copyright IN the Distribution of Films 30-32 (2011), http://www.wipo.int/edocs/pubdocs/en/copyright/950/wipo_pub_950. pdf [https://perma.cc/42EW-WXDS]. 
In particular, content producers often use territorial presales agreements with television broadcasters and distributors as a way of obtaining financing at the initial stages of a project. ${ }^{62}$ These agreements make it possible to afford the high initial production costs and can also work as collateral for a production loan from a bank. ${ }^{63}$ Under a typical pre-sale agreement, a distributor in a particular territory provides an advance payment and, in return, the content producer gives the distributor a distribution license on a territory-by-territory basis, providing the distributor the possibility to profit from the investment. ${ }^{64}$ Producers of most major independent movies, including big names such as The Hunger Games and The Wolf of Wall Street, as well as most big European films, finance their works through pre-selling territorial distribution rights. ${ }^{65}$

Besides project funding concerns, producers of audiovisual programs typically grant exclusive distribution licenses with territorial restrictions for other commercial reasons as well. ${ }^{66}$ For one, chosen distributors often have local expertise in their respective territories and are well equipped to cater their distribution strategies for films within markets that a producer may consider foreign or unfamiliar. ${ }^{67}$ In a highly fragmented and heterogeneous market such as the EU's, local expertise on the languages and preferences of the culture in each territory is critically advantageous in the cross-border distribution of films. Second, films may have staggered releases in various nations

$62 I d$.

63 Id.

64 Id. at 31-32.

65 Roxborough, supra note 6.

66 Gomez \& Martens, supra note 34, at 2.

67 BLÁZqUEZ ET AL., supra note 16, at 20; Tal Kra-Oz, Geoblocking and the Legality of Circumvention 11 (Hebrew University of Jerusalem Legal Research Paper No. 15-31, 2014) (on file with author) ("Film studios and music companies long ago recognized the benefits of reaching agreements on the state level with local distribution companies specializing in specific markets ... . [L]ocal companies [are] far more adept at the physical distribution and the tailoring of marketing to local audiences."). 
over an extended period of time. ${ }^{68}$ As one commentator has observed, "reasons for this are both logistical (the costs of global marketing and distribution are high, and a sequential release can help mitigate them) and geo-cultural (traditional "summer blockbusters" released in the United States and Europe in July might be less relevant during those same months in the wintry Southern Hemisphere)." ${ }^{69}$ Based on similar commercial considerations, broadcasters in the digital world may also stagger releases of films and television episodes onto online streaming platforms such as Netflix. These online platforms depend on territorial exclusivity to allow for staggered releases; without them, films and shows would have a practically worldwide simultaneous release once available online in any one territory. Third, territorial exclusivity also allows producers and distributors to charge different prices in different territories for the same product based on price levels and demand for the content in each territory. ${ }^{70}$ This is particularly true for sports programs, where the value of media rights within a team's main market, where the level of interest is highest, can vary substantially from the value of those rights in other markets. ${ }^{71}$ Furthermore, broadcasters

68 See Elsa Keslassy, Why Film Bizzers Are Still Outraged over Europe's Digital Single Market Plan, VARIETY (May 5, 2015), http://variety.com/2015/film/news/digital-single-market-europeancommission-geoblocking-protest-1201487308 [https://perma.cc/D2B653RC]. "Today, a movie can take up to two years to get theatrically released across all of Europe" because "[e]very distributor has its own timeline and strategy." Id. (quoting Daniela Elstner, managing director of Doc \& Film International and vice president of ADEF).

69 Kra-Oz, supra note 67, at 9.

70 Id. at $9,10$.

71 Commission Staff Working Document, supra note 5, at 27 n.116.

Taking the example of professional football, the English Premier League currently sells its media rights annually for EUR 1.3 billion in the UK, and a total of around EUR 200 million in the other 27 EU national territories combined. This reflects the product's primarily national audience, with a value that is much higher in the UK than 
can tailor commentary and advertising specifically to the local crowd according to its interests. ${ }^{72}$ The resulting price and content flexibility from territoriality allows for a more efficient market.

Territorial exclusivity provides incentives for rightsholders to invest in products not only initially, but also on an ongoing basis through content promotion. Within the territorial exclusivity framework, if a film or television series were sold to the entire EU today, it could be contractually licensed separately for upwards of twenty-eight different territories. Vertical agreements between content producers and distributors may contain clauses limiting producers' ability to license domestic or cross-border availability of the relevant content to other distributors. ${ }^{73}$ The buyers of the license in each of those territories, whether they are film distributors, television channels, or streaming video ondemand platforms ("SVoD") like Netflix, need to be certain of their exclusive rights for use and broadcast in those territories. Considering the high investment required for promotional campaigns by local distributors, these distributors only make that investment if there is a reasonable expectation of profit. Without the enforcement of exclusive rights, there is a risk that competing distribution channels (television, DVD, and online), both domestically and abroad, may "benefit from the spill-over effects of [a distributor's] costly ... promotion campaign." ${ }^{24}$ As the EC notes, "[w]ell-defined property rights are a pre-condition for markets to work efficiently." "If If territorial exclusivity were

anywhere else. In France, the rights for Ligue-1 are sold for EUR 700 million, while the income for Ligue-1 from sales in the rest of Europe amount to EUR 70 million. The situation is similar for other national sports competitions.

Id.

72 See Scourfield et al., supra note 15.

73 Gomez \& Martens, supra note 34, at 2.

74 Id. at 18.

75 Commission Staff Working Document, supra note 5, at 28. 
to be eliminated as a viable framework of distribution, "this system falls apart."76

\section{Geo-blocking}

In order to protect the territorial exclusivity of copyright licenses and commercial agreements between broadcasters and producers for digital content, stakeholders employ measures known within the telecommunications industry as "geo-blocking." Geo-blocking measures are "commercial practices that prevent online customers from accessing and purchasing a product or a service from a website based in another member state or which automatically re-routes them to a local site." 77 These measures allow "media content providers to restrict consumers from one Member State from accessing content available in another Member State precisely because the rights holder has licensed the content to the provider on an exclusive territorial basis." 78 Furthermore, "[g]eo-blocking can also restrict customers' access to online services purchased in their home country ... when abroad." 79 When consumers abroad attempt to view geo-blocked content, they are often unable to access it or are automatically redirected to a local version of the website, which may offer a different catalogue than that available in their territory of residence. ${ }^{80}$

To identify the physical location of an online user, content distributors rely on geo-location techniques. ${ }^{81}$ At the most basic level, this could entail a website asking users to selfreport their location from a dropdown menu on the website. ${ }^{82}$ Content distributors may also rely on hardware with GPS capabilities, such as smartphones, to determine a user's

76 Roxborough, supra note 6.

77 BLÁZQUEZ ET AL., supra note 16, at 26.

78 Scourfield et al., supra note 15.

79 BLÁZqueZ ET AL., supra note 16, at 26.

80 Commission Staff Working Document, supra note 5, at 26.

81 Kra-Oz, supra note 67, at 3.

$82 I d$. 
location. ${ }^{83}$ Most commonly, distributors use Internet Protocol ("IP") addresses: geographically based unique numbers assigned to all internet-accessing devices. ${ }^{84}$ IP addresses provide an approximate estimation of the user's location sufficient to determine whether or not to make content available to the user. ${ }^{85}$ Beyond ensuring compliance with a contractual obligation to make copyrighted content available only in certain countries, distributors implement geo-location for various other reasons, such as localization of content (e.g., weather reports) and compliance with domestic laws (e.g., preventing access to gambling sites in countries where online gambling is illegal). ${ }^{86}$ The geo-blocking of streaming technologies enables territorial exclusivity in audiovisual licensing deals at a degree previously unfeasible, allowing for an "infinitely more comprehensive classification of markets." 87

While geo-blocking is a crucial tool for the audiovisual industry, many regard it as a nuisance. For one, international travelers often find the effects of geo-blocking inconvenient and infuriating. ${ }^{88} \mathrm{~A}$ resident of Germany travelling on business to neighboring France may be unable to access the same German content he purchased while at home. Instead, due to geo-blocking, he will receive a message stating that the content is not available. Consumers in smaller countries where content producers have not yet

$83 I d$.

$84 \mathrm{Id}$.

$85 \mathrm{Id}$.

86 See Marketa Trimble, The Future of Cybertravel: Legal Implications of the Evasion of Geolocation, Fordham Intell. Prop. MEdia \& EnT. L.J. 567, 592-93 (2012).

87 Kra-Oz, supra note 67, at 11.

88 See Cécile Barbière, Geo-Blocking Attacked From All Sides, EurActiv.COM (Samuel White trans., Mar. 12, 2015), http://www.euractiv. com/sections/infosociety/geo-blocking-attacked-all-sides-312811 [https:// perma.cc/PK7X-B5Y2] ("Andrus Ansip, Commission Vice-President for the Digital Single Market, complained about geo-blocking . . . 'If I can watch a football match in Estonia, but not in Brussels, it is quite simply unfair,' he told MEPs at his European Parliament hearing."). 
licensed their product to an online platform (e.g., Netflix) due to market dynamics also have reasons to dislike the effects of geo-blocking. Often these consumers will be unable to legally view the content. For instance, an Internet user in Lithuania who wishes to view programs on the BBC's iPlayer is out of luck. ${ }^{89}$ Lastly, due to the price discrimination practices discussed above, residents of countries that are charged higher prices for the same content selling at much lower prices in neighboring territories may feel that the effects of geo-blocking are unfair. Because of these various frustrations, geo-blocking circumvention is a growing trend.

\section{Circumvention and VPN}

As markets and legislatures work to respond to the consumer demand for portability and cross-border availability, consumers have begun to take matters into their own hands. By utilizing various circumvention techniques, a consumer can bypass existing geo-blocking barriers and access content that is not licensed for availability in their nation of residence. For instance, piracy is one of the more legally dubious forms of circumvention, such as when a consumer uses file-sharing networks to download unauthorized versions of content. ${ }^{90}$ Currently, "the EU audiovisual industry continues to suffer from high levels of piracy, [the] impact [of which] on the different markets and in particular on the video market is still difficult to anticipate." ${ }^{91}$ Other consumers bypass geo-blocking barriers by use of a proxy, through which consumers reroute their connection via an IP address located remotely. By doing so, consumers can disguise their location with one in a different territory. ${ }^{92}$ This can be done "via a free-to-use website (often

\footnotetext{
89 Spence, supra note 8.

90 Kra-Oz, supra note 67, at 18-19.

91 BLÁZQUEZ ET AL., supra note 16, at 25.

92 Kra-Oz, supra note 67, at 19.
} 
less effective), or a paid subscription service, often referred to as a [Virtual Private Network ("VPN")]."93

The international community currently debates the legality of these various circumvention techniques, a full discussion of which is outside the scope of this Note. ${ }^{94}$ Peerto-peer file-sharing, particularly with respect to those who upload the pirated content, is considered criminal. ${ }^{95}$ The question of legality is less clear-cut with regards to the use of proxies and VPNs. For example, a VPN may be used to subscribe and pay for access to streaming content not available in one's own country. ${ }^{96}$ Although the copyright holder may receive compensation for their work from the VPN user, attempting to misrepresent one's IP address could be considered an act of fraud. ${ }^{97}$ On the international level, the WIPO Copyright Treaty of 1996 ("WIPO Treaty") gives some weight to the illegality of circumvention. According to Article 11 of the WIPO Treaty: "Contracting Parties shall provide adequate legal protection and effective legal remedies against the circumvention of effective technological measures that are used by authors in connection with the exercise of their rights ..."98 The treaty does not explicitly state that circumvention is illegal; instead, contracting parties must protect against circumvention. Businesses can avoid uncertainty through contractual terms of service, such as an agreement provision stating that a subscriber may only use the service or content within the country in which a subscription account was established or in geographic

93 Id.

94 For a more complete inquiry into the legality of circumvention, see Kra-Oz, supra note 67.

95 Id. at 19; see also Brendan Sasso, Crackdown on Illegal File Sharing Begins, THE HiLl (Feb. 25, 2013, 4:30 PM), http://thehill.com/polic y/technology/284661-internet-providers-crack-down-on-illegal-file-sharing [https://perma.cc/FRM2-9QEL].

96 Kra-Oz, supra note 67, at 29.

97 Trimble, supra note 8686, a 636.

98 WIPO Copyright Treaty art. 11, Dec. 20, 1996, S. Treaty Doc. No. 105-17 (1997), 36 I.L.M. 65. 
locations where the subscription service is offered. ${ }^{99}$ Under such terms, use of circumvention to access a service outside the licensed territory would "appear to almost always constitute a breach of contract" and give copyright holders a cause of action. ${ }^{100}$

Evasion of geo-blocking barriers may become easier or more difficult in the future, depending on the technological advancement of mechanisms used to detect VPNs on the one hand and those used to increase their accessibility on the other. One factor indicating the increased ineffectiveness of VPNs is "the increasing prevalence" of GPS enabled devices that "utiliz[e] satellites to pinpoint precise geographical locations" independent of a given IP addresses. ${ }^{101}$ On the other hand, while the use of methods of circumvention such as VPN "requires fairly advanced technological prowess"102 at this point, as technological literacy grows, it is likely circumvention will become more prevalent. Younger consumers have come to expect access to their favorite shows and sporting events without having to wait for a licensing agreement to occur for their territory. As Jörgen Gren, adviser to EC Vice-President for the DSM Andrus Ansip, pointed out, "[o]ne in five Europeans are already using a [VPN] to bypass territorial restrictions and stream shows from other countries." 103 As technological literacy among Europeans increases, that number could grow. Beyond VPNs, many others continue to illegally pirate content through sites that allow users to download and share copyrighted content free of charge. ${ }^{104}$ An increase in circumvention of geo-blocking measures directly challenges the effectiveness and utility of a legal framework of territorial exclusivity. ${ }^{105}$

\footnotetext{
99 Kra-Oz, supra note 67, at 22.

$100 \mathrm{Id}$.

101 Id. at 19

102 Id.

103 Spence, supra note 8.

104 Id.

105 Kra-Oz, supra note 67, at 33-34.
} 


\section{THE DSM: PROBLEMS TO ADDRESS, PROPOSED REFORMS, AND POTENTIAL RAMIFICATIONS}

\section{A. Problems Within the EU's Digital Audiovisual Industry}

\section{Falling Behind Internationally}

The DSM is in part a response to the EU's desire to become more competitive on a global scale within the digital industries. Approximately 315 million Europeans use the Internet every day. ${ }^{106}$ Accessing copyright-protected digital content is the most common online activity; " $35 \%$ of Internet users engage in playing/downloading of games, images, films, or music." ${ }^{107}$ However, as the significance of online digital content grows, so too does the EU's fear of trailing the United States and other nations in adapting to the demands of an Internet-based society. The make-up of Europe's digital market is currently 54\% US-based online services, $42 \%$ national online services (i.e., content produced and viewed within a single Member State), and 4\% EU cross-border online services. ${ }^{108}$ The manner in which geo-blocking has enabled a fragmentation of the EU market into virtually twenty-eight sub-markets runs contrary to the EU's overall goal for a unified Single Market. ${ }^{109}$ Miriam Sapiro, a senior fellow at the Brookings Institute and a former Deputy U.S. Trade Representative, believes the fragmentation of the EU market is "bad for investment, innovation, and, most of all,

106 European Commission, Why We Need a Digital Single Market 1 (2015), http://ec.europa.eu/priorities/sites/beta-political/files/dsm-factsheet _en.pdf [https://perma.cc/J278-AR67] [hereinafter EUROPEAN COMMISSION FACTSHEET].

107 Commission Staff Working Document, supra note 5, at 25.

108 European Commission FACTSHeEt, supra note 106, at 1.

109 See Mark Scott, Europe Plans to Ease Copyright Rules on Using Digital Content, N.Y. TIMES (Dec. 8, 2015), http://www.nytimes.com/2015/1 2/09/technology/europe-plans-to-ease-copyright-rules-on-using-digitalcontent.html [https://perma.cc/42GP-HCH5]. 
consumers."110 Further, she argues that "Europe has been lagging in terms of cross-border digital trade, investment, infrastructure, and skills." ${ }^{111}$ The EC hopes that the reduction of EU cross-border barriers will support the growth of EU online networks and platforms and allow them to scale-up and compete globally. ${ }^{112}$ Between 2001 and 2011, Information and Communications Technology ("ICT") accounted for $55 \%$ of gross domestic product ("GDP") growth in the U.S., but only $30 \%$ of GDP growth in the EU. ${ }^{113}$ The EC believes this disparity is due at least in part to the "sectoral composition of the corresponding economies" in the EU. ${ }^{114}$ In particular, the "fragmentation of online rights along [Member States'] borders" due to copyright's rule of territoriality "entails huge transaction and licensing costs" for those offering content online across the EU. ${ }^{115}$ Commentators have argued these high transaction costs "put[] European content service providers at a large competitive disadvantage, particularly when compared to competitors in the United States, where copyright is regulated at the federal level and no state-by-state licensing is required." 116 The EU expects the reforms included in the DSM to finally create the opportunity needed to close the gap between the EU and the United States in terms of digital growth. ${ }^{117}$ As Ansip puts it, the EU feels that they "have to hurry up . . or we will get left behind."118

110 Miriam Sapiro, Forging an EU Digital Single Market: Difficulties and Opportunities, Brookings InstituTE: UP Front (Sept. 22, 2015), http://www.brookings.edu/blogs/up-front/posts/2015/09/22-european-uniondigital-single-market-sapiro [https://perma.cc/QQ69-7R6Q].

111 Id.

112 Id.

113 Commission Staff Working Document, supra note 5, at 5.

114 Id.

115 HugenHOLTZ, supra note 19 , at 13.

$116 I d$.

117 Commission Staff Working Document, supra note 5, at 5.

118 Roxborough, supra note 6. 
2. Changes in Consumer Behavior and the Demand for Cross-Border Portability and Accessibility

In addition to the EU's aspirations to be competitive on a global level, the DSM is also a direct response to changes in consumer behavior and the dynamics of the audiovisual marketplace. Over the next five years, "global digital spending on entertainment and media is expected to increase at a rate of $12.1 \%$." 119 European smartphone users already "consume more than four hours of video content on a weekly basis, almost half of which they view on-the-go." ${ }^{20}$ In response, "the availability of legal online offers of digital content" has also risen, with over " 2,500 on-demand audiovisual services available in Europe at the end of 2014." ${ }^{121}$ The EC expects growth in key copyright-intensive industries to continue globally in upcoming years, mostly driven by digital content, with "'Over the Top' [("OTT")]/streaming services . . . see[ing] the fastest rates of growth (28.1\% [Compound Annual Growth Rate ("CAGR")])."122 With the EU audiovisual market's value experiencing a slight decline in 2013 to $€ 132.7$ billion ( $-0.4 \%$ growth), a year after complete stagnation in $2012(0 \%$ growth), the EU has a strong incentive to capture this growth internally. ${ }^{123}$

To grow the value of its audiovisual sector, the EU must meet the rapidly evolving demands of consumers and businesses. With the rise of OTT distribution of audiovisual content and the multitude of connected devices that are enabled to stream OTT content, the audiovisual industry now operates in a "multi-screen environment." ${ }^{24}$ Gone are the days of audiences being "captives" to a single television

\footnotetext{
119 Commission Staff Working Document, supra note 5, at 25.

$120 \mathrm{Id}$.

121 Id. at 25-26.

122 Id. at 25 .

123 BLÁZQUEZ ET AL., supra note 16, at 9.

124 Id. at 9-10.
} 
set or cinema with a limited amount of content. ${ }^{125}$ Instead, "[g]lobal OTT SVoD revenues are . . to grow from USD 7.5 billion in 2014 to USD 21.6 billion in 2020, thereby making SVoD services the largest source of revenue for OTT video." ${ }^{26}$ Meanwhile, cinema attendance is in decline, traditional pay-TV revenues are stagnating, and the video/DVD market continues to dwindle. ${ }^{127}$ The rise of ondemand and on-the-go digital content viewership has created a demand for portability and accessibility of digital media content in cross-border situations. ${ }^{128}$ This "soaring demand . . . to watch films and TV shows from other countries over the Internet is driving a 'paradigm change' in European media." 129 The market has shifted "from a closed and regulated media environment, where content was under the control of right-holders, to an open one that's difficult to regulate." 130 The EC reports that " $27 \%$ of [all] citizens . . . would be interested in watching or listening to audiovisual content or music transmitted from their home country" while traveling abroad. ${ }^{131}$ Additionally, " $19 \%$ of citizens are interested in watching or listening to content from other EU countries" foreign to their own. ${ }^{132}$ The statistics indicate a clear demand within the EU for cross-border portability and accessibility of audiovisual content.

Due to the territorial nature of the audiovisual market and the use of geo-blocking, however, the market is struggling to meet this consumer demand for cross-border portability and accessibility. A consumer survey conducted by the EC showed that, "of the $31 \%$ of [the survey's] respondents who streamed films and TV series in the last 12 months and tried to access streaming services of their own

125 Id. at 10.

126 Id. at 12 .

127 Id. at 24-25.

128 See Commission Staff Working Document, supra note 5, at 26.

129 Spence, supra note 8.

130 BLÁZQUEZ ET AL., supra note 16, at 10.

131 Commission Staff Working Document, supra note 5, at 26.

132 Id 
country while being abroad, $43 \%$ reported not being able to access the content when abroad." 133 Likewise, "of the $38 \%$ of respondents who streamed live events . . . in the last 12 months and tried to access streaming services of their own country while abroad, 51\% reported [failing]."134 Between December 2013 and March 2014, the EC conducted a public consultation on the review of the EU copyright rules, generating more than 9500 replies. ${ }^{135}$ On the one hand, authors, producers, and broadcasters saw a continued need to restrict rights on a territorial basis and to guarantee full exclusivity to distributors. ${ }^{136}$ On the other hand, a "vast majority of end user/consumer respondents report[ed] facing problems when trying to access online services in another EU country" and stated that "they are regularly confronted with access restrictions depending on the geographic location of their IP address." ${ }^{137}$ In general, respondents stated that they wished to "access all content from any online stores whether directed to the Member State in which they reside or not" and "consider the blocking of content to be mostly arbitrary and unpredictable." ${ }^{38}$ European legislators are now faced with the task of meeting the demands of an increasingly globalized consumer base that expects to be able to enjoy the audiovisual service they paid for, regardless of their geographical location.

$133 I d$.

$134 I d$.

135 See BLÁZQUEZ ET AL., supra note 16, at 63.

136 Id. at 64 .

137 European Comm’n, Directorate Gen. For Internal Mkt. AND Servs., Report on the Responses to the Public Consultation on the REVIEW OF THE EU COPYRIGHT RULES 6 (2014), http://ec.europa.eu/internal _market/consultations/2013/copyright-rules/docs/contributions/consultati on-report_en.pdf [https://perma.cc/Y6MN-N5WM] [hereinafter EU CoPYRIGHT CONSULTATION].

138 Id. at 6-7. 


\section{Market Segmentation}

An inevitable effect of the use of geo-blocking barriers within the EU is the segmentation of the market. Notwithstanding the EU's concentrated efforts to form a Single Market, the European market, divided into twentyeight Member States with twenty-four official languages (and many other unofficial languages), remains deeply segmented both physically and culturally. ${ }^{139}$ This geographical segmentation and lack of cross-border availability of digital content is often attributed to the territoriality of the EU copyright regime. ${ }^{140}$ A study conducted by the EC's Joint Research Centre ("JRC") found that "[c]onsumer preference variables such as cultural proximity, a shared language or border[,] and inherent preferences for home market products are the main drivers" of market segmentation for music and film. ${ }^{141}$ Based on the JRC report, it is evident that cross-border audiovisual content availability in the EU is limited. Only around $40 \%$ of all films offered on a major online distribution platform are available in the twenty-seven national country stores, lower than that of music (approximately 80\%). ${ }^{142}$ For EU-produced films, the availability goes down to about $28 \% .{ }^{143}$ The JRC report theorized that this was due to the higher cross-border trade cost for film relative to music. ${ }^{144}$ These higher costs include high translation costs, contractual agreements between producers and distributors restricting availability (i.e., territorial exclusivity), and higher copyright clearance

139 See Gomez \& Martens, supra note 34, at 1-4.

140 Id.; see also Commission Staff Working Document, supra note 5, at 27.

141 Gomez \& Martens, supra note 34, at 1.

$142 I d$. at 21 ("Using data from the Apple iTunes country stores, the dominant provider of digital media downloads in the EU, we find that availability is in the 73-82 per cent range for music and around 40 per cent for film.").

$143 I d$. at 17.

144 Id. at 18 . 
costs. ${ }^{145}$ Cross-border accessibility of digital content may also be affected by other factors such as tax considerations, lack of demand in certain regions, or a "lack of incentives for right holders to make their content available online due to fear of illegal exploitation (e.g. piracy)." ${ }^{46}$ The JRC study determined that, on average, films were available on the Apple iTunes store "in 1.1 language versions per country store ... [meaning] most films are available in only one language in each store." ${ }^{147}$ In the JRC study's survey of overall film availability in the EU iTunes stores, they determined that about $30 \%$ of all films are available in only one or two countries, while only around $10 \%$ of films are available in almost all EU countries. ${ }^{148}$ For Video-onDemand ("VoD"), the EC determined that less than 4\% of legally available content in the EU is accessible crossborder. ${ }^{149}$ In sum, if the EU is expecting to create a truly open DSM that includes $100 \%$ cross-border availability of digital content, they have a long way to go. Ending the market fragmentation caused by the use of geo-blocking measures would be a large step towards that end, but, as discussed below, may have costly ramifications.

\section{B. The DSM Strategy_Proposed Actions}

\section{Background}

In response to these emerging issues in the audiovisual industry, as well as concerns relating to various other sectors of the European economy, the EC identified the completion of the DSM as one of its ten political priorities. ${ }^{150}$ The DSM

145 Id.

146 Commission Staff Working Document, supra note 5, at 28.

147 Gomez \& Martens, supra note 34, at 17. The study went on to observe that within a given Member State, "89\% of all films are available in one language only, in most cases either in English or in the official language of the country." Id. at 18.

148 Id. at 17.

149 BLÁZQUEZ ET AL., supra note 16, at 65.

150 See Juncker, supra note 2. 
strategy, unveiled in May 2015, sets out sixteen key actions built upon three pillars: "(1) better access for consumers and businesses to digital goods and services across Europe; (2) creating the right conditions and a level playing field for digital networks and innovative services to flourish; (3) maximizing the growth potential of the digital economy." 151 The DSM is a "broad umbrella term," "cover[ing] initiatives ranging from legislative measures to more general studies and aspirational goals." ${ }^{152}$ Many of the actions listed are commitments to study issues and review rules rather than take concrete actions. ${ }^{153}$ Some have observed that the range of measures indicates a fundamental disagreement within European institutions on what the main objective of the DSM should be. ${ }^{154}$ On the one hand, some view the DSM "as a genuine opportunity to remove regulatory barriers, and thereby give digital businesses greater freedom to innovate"; others see it as an opportunity to extend existing regulations to these digital businesses, thereby leveling the playing field and protecting traditional business from the emerging disruptive ones. ${ }^{155}$

\section{The EC's December 2015 Proposed Regulations}

Two of the actions announced under Pillar I of the DSM strategy in May 2015, copyright reform and the end of unjustified geo-blocking, directly affect the audiovisual sector and address the problems discussed above concerning crossborder portability and accessibility of online content. On

151 European Commission Press Release IP/15/4919, supra note 1.

152 Client Alert, Cooley LLP, European Commission Launches Digital Single Market Strategy with a Laundry List of Measures, Including Antitrust Sector Inquiry (May 21, 2015), https://www.cooley.com/news/insight/2015/european-commission-launchesdigital-single-market-strategy-with-a-laundry-list-of-measures-includingantitrust-sector-inquiry [https://perma.cc/B6VF-TAEU] [hereinafter Cooley Alert].

153 Id.

$154 I d$.

155 Id. 
908

December 8, 2015, the EC released its first set of DSM draft proposals on moving towards a "modern, more European copyright framework." 156 Since geo-blocking is largely the result of territoriality within copyright licenses, copyright reform and geo-blocking are fundamentally linked. ${ }^{157}$

\section{a. Unjustified Geo-Blocking}

One of the most significant proposals the EC released in December 2015 was a regulation aimed at ensuring the cross-border portability of online content in the EU (the "Proposed Regulation"). ${ }^{158}$ The Proposed Regulation provides that subscribers of online content who are temporarily in another Member State must be granted the same access that they would be permitted in their home Member State, without any limitations as to functionality, range of content, or devices used. ${ }^{159}$ The Proposed Regulation also provides that contractual provisions between rights-holders and service providers that restrict or prohibit such portability will be unenforceable. ${ }^{160}$ The Proposed Regulation is expected to take effect as early as 2017. It will apply to all future contracts and retrospectively to all contracts concluded prior to its adoption. ${ }^{161}$ The European Parliament and the twentyeight Member States, however, must first approve the new rules, a process that may involve a significant amount of bargaining over the details. ${ }^{162}$ Media industry concerns regarding the Proposed Regulation include the accuracy of geo-location mechanisms in authenticating a consumer's Member State of residence so that this cross-border portability is not abused. ${ }^{163}$ Some stakeholders fear that

\footnotetext{
156 Scourfield et al., supra note 15.

157 Jansen, supra note 13.

158 Scourfield et al., supra note 15 .

159 Id.

$160 \mathrm{Id}$.

161 Id.

162 Scott, supra note 109.

163 Scourfield et al., supra note 15.
} 
ineffective geo-location mechanisms will allow consumers "to 'shop around' and purchase online content services in Member States offering the best price." 164 Another concern centers around what constitutes being "temporarily" in another Member State, as the Proposed Regulation does not give any guidelines or clear-cut rules on this issue. ${ }^{165}$

The EC's underlying objective is "to end unjustified geoblocking." 166 According to the EC, geo-blocking restrictions can be justified, for example, "where the provider of services has to comply with specific legal obligations (e.g. consumer law) or when it is due to acceptable business practices (e.g. higher delivery costs)." 167 It is unclear, however, if all geoblocking mechanisms used in the audiovisual sector to enforce territorial exclusivity will be considered justified or not. 168

Prior statements made by the EC's leaders heading the DSM strategy have sent mixed signals. Ansip "has described geo-blocking as fundamentally incompatible with the concept of an internal market." 169 He has been outspoken in his desire to do away with geo-blocking. ${ }^{170}$ Margrethe Vestager, the EC's Competition Commissioner, "says that geo-blocking arrangements, where broadcasters restrict access to movies and shows according to which country the user is in, go against the spirit of the single market." ${ }^{171}$ As she puts it, "I, for one, cannot understand why I can watch my favorite Danish channels on my tablet in Copenhagen, a service I

$164 I d$.

$165 I d$.

166 European Commission Press Release IP/15/4919, supra note 1.

167 BLÁZQUEZ ET AL., supra note 16, at 65.

$168 I d$.

169 Client Alert, supra note 152.

170 See Robinson, supra note 10.

171 Adrian Weckler, Europe Says Consumers Are Losing Out Because of Digital Borders, INDEPENDENT.IE (June 10, 2015, 2:30 PM) http://www.independent.ie/business/technology/news/europe-saysconsumers-are-losing-out-because-of-digital-borders-31585152.html [https://perma.cc/6KPH-73GE]. 
paid for, but I can't when I am in Brussels." 172 This sort of portability problem was the focus of the Proposed Regulation. ${ }^{173}$ On the other hand, Günther Oettinger, the former EC Commissioner for the Digital Economy and Society and current EC Commissioner for Budget and Human Resources, believes that the EC's plans for a DSM should preserve the principle of territoriality for the European film industry. ${ }^{174}$

As it stands now, the December 2015 proposals seem to indicate that geo-blocking is unjustified when it restricts a consumer's access to their purchased digital content subscriptions while temporarily in another Member State. Should future regulations go no farther than that, at least some sense of territoriality will be able to remain within the EU. The cross-border portability regulation carves away at the exclusivity producers and distributors have enjoyed with their licenses thus far by forcing them to give consumers access to content outside their licensed territory. However, the Proposed Regulation may lead to a better outcome for producers than a blanket prohibition on geo-blocking altogether. ${ }^{175}$ Media executives in the EU fear that the current discussion of portability will eventually lead to universal cross-border access, thereby eliminating territorial exclusivity in licensing deals. ${ }^{176}$

Should the EC later determine all territorial licensing used in the audiovisual sector is unjustified, one possible legislative reform would be to amend the SD to include audiovisual and cinematographic services, which currently

$172 I d$.

173 Scourfield et al., supra note 15.

174 Martin Blaney, Digital Single Market: Oettinger Stresses Special Case for Film Industry, SCREEN DAILY (Oct. 27, 2015), http://www.screenda ily.com/news/dsm-oettinger-stresses-special-case-for-film-industry/509599 8.article [https://perma.cc/Y3UB-QC62].

175 Scourfield et al., supra note 15.

176 Elsa Keslassy, World Industry Reacts To Digital Single Market Proposals, VARIETY (Dec. 9 2015, 8:46 AM), http://variety.com/2015/film/ne ws/french-orgs-reacts-to-european-commissions-reform-on-copyright1201657190 [https://perma.cc/AV6Q-5E3M]. 
do not fall under the SD. ${ }^{177}$ The SD is the key EU legal instrument used to implement the freedom to provide and receive services, and includes principles of nondiscrimination. ${ }^{178}$ "Article 20 [of the] SD prohibits discriminatory requirements based on the nationality or place of residence of the recipient of the service."179 Currently, Article 17(11) states that the SD's rules on the freedom to provide services do not apply to copyright in general, thereby confirming the principle of territoriality in copyright law. ${ }^{180}$ Furthermore, an explicit exception to Article 20 exists for objectively justified reasons. The EC considers the lack of the required authorization from a rightholder for a territory in question as an objective reason to justify the refusal of service to a consumer in that territory. ${ }^{181}$ Lastly, specifically relevant to territoriality in the audiovisual industry, Article $2(2)(\mathrm{g})$ provides that "the Services Directive does not apply to 'audiovisual services, including cinematographic services, whatever their mode of production, distribution and transmission, and radio broadcasting." "182 If the EC were to amend these provisions and extend the SD to include audiovisual services, the legality of standard licensing and distribution practices within the audiovisual sector would be in serious question.

\section{b. Modernization of European Copyright Law}

Oettinger considers the EU's copyright rules outdated and "drafted at a time where many of today's possibilities to discover, disseminate and share ideas and knowledge did not

177 BLÁZQUEZ ET AL., supra note 16, at 65.

178 Id. at 28 .

179 Id.

$180 I d$.

181 Id.

182 Id. (quoting Directive 2006/123/EC of the European Parliament and of the Council of 12 December 2006 on Services in the Internal Market, art. 2, 2006 O.J. (L 376) 51). 
exist."183 The EC, therefore, calls for a "modern, more European copyright law" and announced forthcoming legislative proposals "to reduce the differences between national copyright regimes and allow for wider online access to works across the EU." ${ }^{84}$ To this end, EC President Juncker announced his intention to "break down national silos" in copyright legislation, among other areas of regulation. ${ }^{185}$ The ultimate goal is the reduction in legal uncertainty and transaction costs for businesses and rightowners participating in cross-border economic activity.

For instance, the EC likely will aim to "harmoniz[e] exceptions to copyright for essential activities such as research, education, text and data mining." ${ }^{86}$ Currently, EU copyright rules "provide an exhaustive catalogue of exceptions to copyright"; each Member State can then decide which exceptions to implement in their national copyright laws. ${ }^{187}$ The disparities between different nations' exception rules create transaction costs for companies looking to offer products and services in foreign Member States. ${ }^{188}$ In the end, the legal uncertainty may prevent companies from offering their services in those Member States. ${ }^{189}$ The EC's reform will likely implement mandatory minimum standards for user rights in copyright. ${ }^{190}$

Most radically, the EC could enact a unified EU copyright law to foster the DSM for audiovisual works. Supporters of the unification of EU copyright law deem it the most fundamental way to solve the problem of territoriality in copyright, "a truly structural and consistent solution, which

183 Benedicte Page, Oettinger Promises 'Balance' on Copyright, BoOKSELLER (Oct. 16, 2015), http://www.thebookseller.com/news/oettingerpromises-balance-copyright-314735 [https://perma.cc/3J6P-T6UB].

184 European Commission Press Release IP/15/4919, supra note 1.

185 Juncker, supra note 2.

186 Jansen, supra note 13.

$187 I d$.

$188 I d$.

$189 I d$.

$190 \mathrm{Id}$. 
would immediately remove all copyright-related territorial obstacles to the creation of a Single Market." ${ }^{191}$ The Treaty of Lisbon ${ }^{192}$ "introduced a specific competence" to the EU regarding the protection of intellectual property rights; ${ }^{193}$ Article 118 of the Treaty on the Functioning of the European Union provides:

In the context of the establishment and functioning of the internal market, the European Parliament and the Council, acting in accordance with the ordinary legislative procedure, shall establish measures for the creation of European intellectual property rights to provide uniform protection of intellectual property rights throughout the Union and for the setting up of centralized Union-wide authorization, coordination and supervision arrangements. ${ }^{194}$

Based on this provision, some have argued that the EU is concurrently empowered "to introduce Union-wide copyright titles" and provide for "the simultaneous abolishment of national titles, which would be necessary for such an initiative to take its full effect and remove territorial restrictions." 195 The effect would establish a truly unified copyright framework and replace the current regime: a varying network of national rules. ${ }^{196}$ However, while supporters believe the immediate effect would be a single market for copyrights, ${ }^{197}$ it is unclear whether removing the

191 HugenholTz, supra note 19, at 17.

192 Treaty of Lisbon Amending the Treaty on European Union and the Treaty Establishing the European Community, Dec. 13, 2007, 2007 O.J. (C 306) [hereinafter Treaty of Lisbon].

193 HugEnHOLTZ, supra note 19, at 17.

194 Consolidated Version of the Treaty on the Functioning of the European Union art. 118, October 26, 2012, 2012 O.J. (C 326) 96 [hereinafter TFEU].

195 BLÁZQUez ET AL., supra note 16, at 32 (quoting MireILle VAN EECHOUd ET AL., Harmonizing European Copyright Law-The Challenges of Better Lawmaking, in 19 Information LAW SERIES 353 (P. Bernt Hugenholtz ed., 2009)).

196 HugENHOLTZ, supra note 19, at 17.

197 Id. 
principle of territoriality in copyright directly leads to the removal of territorial restrictions. ${ }^{198}$ Even without copyrightrelated territorial barriers, right-holders could still limit the scope of licenses via contractual practices, assuming they conform to EU competition rules. ${ }^{199}$

\section{Why Territorial Exclusivity Should be Preserved: Economic and Cultural Costs}

In response to the DSM proposals, media industries have been generally apprehensive. ${ }^{200}$ In particular, industry stakeholders balk at the notion of an established system of territorial licensing potentially being abolished through a ban on geo-blocking and reformation of the principle of territoriality in copyright. ${ }^{201}$ The industries' legitimate concerns focus on both economic and cultural considerations, as both are inescapably linked in this context. ${ }^{202}$ If the DSM eventually eliminates effective territoriality restrictions, "many have argued that only the largest European content providers would be able to [compete and] afford panEuropean rights." ${ }^{203}$ In turn, the reduced competition could significantly reduce rights-holders' licensing and advertising revenues. ${ }^{204}$ Furthermore, with the creation of pan-European licensing deals, there may not be significant enough demand for smaller regional works to justify the investment in them, thereby reducing the equality and variety of European content produced, particularly for minority languages and cultures. $^{205}$

198 BLÁZQUEZ ET AL., supra note 16, at 32.

199 Id.

200 See Edwards \& Tobias, supra note 6; see also Roxborough, supra note 6; Spence, supra note 8.

201 See Roxborough, supra note 6.

202 See Scourfield et al., supra note 15.

203 Id.

$204 \mathrm{Id}$.

205 Id. 


\section{Economic}

In addition to reducing the amount of European content being produced, elimination of exclusive territorial rights in the EU would also reduce the amount of competitive European producers. As discussed above, content producers have traditionally financed their risky projects through the sale of distribution rights in individual territories. ${ }^{206}$ With the elimination of geo-blocking barriers between countries, studios and producers would no longer be able to sell the same content repeatedly in multiple territories. Instead, they would be forced to sell a pan-European license at a much higher price tag. Competition among audiovisual license broadcasters for these limited pan-European licenses would intensify; only a handful of big players would be able to purchase the premium content and survive. However, as the number of big-name distributors dwindles, the remaining few would gain more negotiating leverage against studios and producers during license negotiations, leading to a decrease in potential earnable revenue.

The removal of territorial licensing within the EU would not exclusively produce losers in the global audiovisual market. Large American streaming services, such as Netflix and Amazon Instant video, stand to benefit significantly from a pan-European market since they are among the few firms with the resources and infrastructure to purchase panEuropean rights for premier shows and films. ${ }^{207}$ Emerging online streaming services located in smaller territories, which may have been able to thrive in their local market, would be unable to compete with the big names on the international level. The three main U.S. SVoD services (Netflix, Amazon, and Hulu) spend nearly $\$ 7$ billion on content and already have begun to make multi-territory licensing deals with right-holders, increasing their international presence across the continent. ${ }^{208}$ This gives

206 See supra Section II.B.1.

207 See Spence, supra note 8.

208 BLÁZQUEZ ET AL., supra note 16, at 12-13. 
them a significant first-mover advantage relative to smaller players should the EU shift into a pan-European framework for licensing. The ability of the major SVoD services to operate on an international level, combined with the increasing licensing costs of content, will exclude smaller players from gaining access to premium audiovisual content. ${ }^{209}$ Currently, the risk of a few American players controlling the audiovisual landscape is already "high," with "Apple (paid entertainment), Facebook (advertising), Google (advertising) and Netflix (subscription video) . . . already dominating their respective markets." ${ }^{210}$ European players are left scrambling "to find successful strategies in order to exist in the online landscape." ${ }^{211}$ Broadening the geographic scope of licenses and increasing the costs of content acquisition may be serious burdens for European players already struggling to compete.

The EU may look to consolidate the European digital market and create audiovisual giants that can compete with U.S.-headquartered market leaders like Google and Netflix. By reducing the number of EU distributors, larger players could swallow up smaller players as the market defragments, allowing the remaining giants to scale up and compete with their American rivals. ${ }^{212}$ Unfortunately, American companies may already have the competitive advantage of being in a large, monolingual market. The EU may be adopting an overall protectionist approach in enacting policies targeted at U.S. companies currently dominating the EU's digital market. ${ }^{213}$ However, as stated above, American rivals will

209 Id. at 13.

210 Id. at $15-16$.

211 Id. at 16.

212 Leo Sun, The EU Takes on Walt Disney Co., Time Warner, Inc., and Other Studios, Motley Fool (Aug. 1, 2015), http://www.fool.com/inves ting/general/2015/08/01/the-eu-takes-on-walt-disney-co-time-warner-incand.aspx [https://perma.cc/3WGM-7TDG].

213 See David Fidler, The Digital Single Market Strategy Will Complicate the Economic Relationship Between the United States and Europe, Council on Foreign ReL.: Net Politics (May 6, 2015), http://blogs.cfr.org/cyber/2015/05/06/the-digital-single-market-strategy- 
likely welcome the ability to easily purchase pan-European licenses. Thus, this protectionist approach "could hurt smaller EU businesses more than it [would] hamper [their] U.S. rivals." 214 Furthermore, as discussed below, losing smaller, localized EU businesses would negatively affect cultural diversity within the EU as well.

\section{Cultural}

The EC's stated aim of harmonizing national copyright regimes and increasing cross-border online access to content is to "improve people's access to cultural content onlinethereby nurturing cultural diversity." ${ }^{215}$ In reality, however, the reforms the EU enacts may have the opposite effect.

[T] he audiovisual industry has raised legitimate concerns that the complete removal of the territoriality principle would marginalise minority languages and cultures, where it is not efficient for large organisations to operate, leading to less investment in local and culturally diverse content and less opportunity for local sponsorship and product placement. ${ }^{216}$

As discussed above, a single market European licensing zone would open doors for broader offerings to dominate markets. The consequence is that it will be much more difficult for smaller platforms in local languages to survive. ${ }^{217}$ Kristen Niehuus, an executive at German film and television funding body Medienboard BerlinBrandenburg, believes a single market European zone would virtually "eliminat[e] European co-productions and endanger[] the entire European movie industry[, stating:] 'A

will-make-economic-relations-between-europe-and-the-u-s-more-difficult [https://perma.cc/VQK5-Z43B].

214 Sun, supra note 212.

215 European Commission Press Release IP/15/4919, supra note 1.

216 See Edwards \& Tobias, supra note 6.

217 Keslassy, supra note 68. 
world without European films would be possible to live in, but only if you don't care about culture.""218

With respect to SVoD services, some are uneasy with the idea of subscribers of streaming content services encountering wildly varying content while travelling abroad due to geo-blocking and inconsistencies between how different countries offer the services. ${ }^{219}$ However, such variation may be to the benefit of both service providers and consumers. The ability to create different versions in different areas of the EU allows a service provider to cater its service to the specific demands of a territory, such as providing locally produced films in the territory's native language. With the creation of a pan-European copyright framework, such variety would likely be lost.

The EC should keep in mind that copyright is a keystone of the creative industries. As discussed, a copyright legal framework "plays an essential role in providing incentives for creativity and for investing in creativity also in the digital environment." ${ }^{220}$ The EU's framework of copyright will directly influence the way Europe's cultural landscape continues to develop and diversify. ${ }^{221}$ EC Commissioner Oettinger recognizes the societal implications in the context of modernizing copyright law and the role of platforms, stating: "platforms do not only influence the way books are written, but in the end also the kind of books that we will read." 222 The same holds true for the audiovisual sector. The DSM copyright and territorial licensing reforms will directly affect which movies the European people make and see. The result could be a shift in European culture away from a diversification of national identities towards a continental

$218 I d$.

219 Kra-Oz, supra note 67, at 12.

220 Commission Staff Working Document, supra note 5, at 28.

221 Eva Paunova, Bringing EU Copyright Rules Into the 21st Century, Digital Post (July 9, 2015), http://www.thedigitalpost.eu/2015/channeldigital-single-market/bringing-eu-copyright-rules-into-the-21st-century [https://perma.cc/9JFD-GQEA].

222 See Page, supra note 183. 
convergence. For now, the Proposed Regulation was limited in scope to the issue of portability, thereby allowing for the survival of territorial exclusivity. ${ }^{223}$ It may be in the best interests of the media industry and European culture in general to limit the reach of future proposals to a similar extent.

\section{BALANCING CONCERNS OF TERRITORIAL EXCLUSIVITY WITH CROSS-BORDER PORTABILITY AND PENDING DEVELOPMENTS IN THE DSM'S IMPLEMENTATION}

\section{A. Potential Solutions}

The rise in the digitization of content significantly impacts the ways copyrighted works and services are created, sold, and consumed. On the one hand, it appears modern consumers expect access to content everywhere from anywhere. On the other hand, content authors and producers expect fair remuneration for their works relative to their usage and dissemination. This tension is particularly acute in the audiovisual industry. The current state of Europe's digital market is highly fragmented and creates unwanted legal uncertainty and transaction costs for those conducting cross-border business. The proposed reforms discussed so far have all been aimed at harmonizing Member States' laws, reducing legal uncertainty, and ultimately increasing portability of audiovisual content throughout the EU. As discussed, in losing the principle of territorial exclusivity in copyright regimes and licensing agreements, rights holders would lose leverage in their financing arrangements and Member States would lose the ability to promote their own cultural values through national laws and contracts. Furthermore, as the stage moves to the pan-European level, smaller Member States and audiovisual businesses may find they are unable to compete with the large American companies dominating the market. Therefore, the EC's goal

223 See Scourfield et al., supra note 15. 
should be to find a way in which it can preserve the principle of territoriality in copyright and rights licensing, yet still allow for portability of content throughout all Member States.

\section{Commercial Considerations}

Regarding the question of portability, there is a growing sentiment among authors, performers, publishers, and broadcasters that the lack of cross-border accessibility does not result from the territorial element of copyright or from problems in licensing, but rather results from the market. That is, consumers do not demand cross-border services, possibly due to cultural and language differences between Member States; therefore, service providers have no business justification to offer them. ${ }^{224}$

Whether European consumer demand exists for crossborder portability, as the EC study discussed above points out, European consumers are at least stating they want it. ${ }^{225}$ However, "[n]othing in national or EU law precludes ... a film or a music producer from giving a multi-territorial licence for more than one country." ${ }^{226}$ Broadcasters believe that the free market "is naturally moving towards addressing [any underlying] demand for cross-border delivery of content where it is economically significant." 227 For example, large U.S. SVoD companies have begun to make multi-territory licensing deals with right-holders and expect to continue to do so in the future. ${ }^{228}$ It may be the case that the EC, in its discussions regarding the DSM and a need for cross-border availability, is glossing over the possibility that "the relative lack of cross-border [availability] . . may stem more from consumer preferences, the (perfectly lawful) unilateral decisions of businesses to focus on selling in a

224 EU Copyright Consultation, supra note 137, at 7.

225 See Commission Staff Working Document, supra note 5, at 26.

226 BLÁZQUEZ ET AL., supra note 16, at 30.

227 EU COPYRIGHT CONSULTATION, supra note 137, at 8.

228 BLÁZQUEZ ET AL., supra note 16, at 12. 
single country and the regulatory barriers such as differential VAT rates that may deter businesses from selling across borders." 229

This Note argues that the territorial nature of copyright and exclusive licensing should be kept intact. However, the EC should promote the practice of multi-territorial licensing through other regulations that lower the transaction costs and legal uncertainty of operating in multiple territories. This is a far less radical approach than eliminating all geoblocking barriers or creating a unified EU copyright law. Lawmakers in Member States would retain the right to promote their own cultural value through national copyright laws based on the economic situation, legal traditions, and cultural policies of their specific Member State. Furthermore, content producers would be able to continue the prefinancing of their projects through licensing deals and utilizing the local expertise of distributors in a particular territory. The underlying principle here is that once the consumer demand for cross-border portability and accessibility is high enough to make it economically reasonable to obtain multi-territory licenses, the market will be able to respond in order to supply what the consumers demand.

\section{B. Ongoing Developments in the DSM Timeline}

With the EC's self-imposed deadline of the end of 2016 quickly approaching, the EC will need to act fast to deliver on the different actions laid out in the DSM. ${ }^{230}$ The DSM strategy in general already faces funding issues, ${ }^{231}$ and a decision from the European Court of Justice on data privacy

229 Cooley Alert, supra note 152.

230 European Commission Press Release IP/15/4919, supra note 1.

231 Daniel Thomas, Europe Faces €106bn Funding Shortfall For Digital Goals, Fin. Times (Oct. 12, 2015, 6:07 PM), http://www.ft.com (search for the title). ("About $€ 216$ bn is needed to meet the EU's digital goals but only $€ 110$ bn of combined public and private investment is being planned, according to research commissioned by some of Europe's largest telecoms groups."). 
could frustrate the EC's attempts to create common data protection laws for the EU. ${ }^{232}$ Nevertheless, the EC remains in an information-gathering phase. Various public consultations are open on subjects relevant to the DSM, including geo-blocking, the AVMSD, the SatCab Directive, and online platforms. ${ }^{233}$ These consultations represent "a significant opportunity for stakeholders to contribute to the shaping of European policy that will have a profound practical impact on business across many industries." ${ }^{234}$ At this point, it seems unlikely that a uniform EU copyright law will be introduced by the end of 2016, in large part "due to the political difficulties of asking each member state to give up their own copyright systems." ${ }^{235}$ In general, the DSM may begin to take a much more concrete shape over the course of the next six months to a year.

\section{CONCLUSION}

Digitization of content has shifted the ways in which copyrighted works are created and consumed. The EC now must respond to both the modern consumer who expects to access audiovisual content anywhere and everywhere, as well as the content producers and distributors who rely on a framework of territorial exclusivity to finance and support their businesses. The EC currently seems determined to defragment the EU's digital online landscape, tear down geoblocking barriers, and unify its Member States' online capabilities. The implications of this strategy may be devastating to both the viability of many European audiovisual producers and the cultural diversity within the EU.

232 Dominic Elliott, EU Data Ruling Could Stunt Single Digital Market, REUTERS: BREAKINGVIEWs (Oct. 6, 2015), http://blogs.reuters.com/b reakingviews/2015/10/06/eu-data-ruling-could-stunt-single-digital-market [https://perma.cc/6WWX-HXL7].

233 Edwards \& Tobias, supra note 6.

$234 I d$.

235 Id 
The problems and discussion presented by the EU's attempt to implement a DSM are indicative of much broader existential issues the EU must face. A clear tension exists between, on the one hand, the interest to harmonize the policies of the EU's Member States and compete on the international scale and, on the other hand, the interest in preserving cultural diversity amongst individual Member States. Ultimately, the EC's values will determine which actions it takes. 